\title{
PACHACAMAC PARK:
}

\section{THE PLINTH AND THE MANTLE}

\author{
PABLO ALFARO, KUSHAL LACHHWANI, TOMÁS MCKAY
}

\section{Keywords}

Pachacamac

Contest

Park

Edge

Sanctuary

Archeology
Vista aérea sitio

Pachacamac / Aerial view

Pachacamac site

(c) Archivo MSPAC
Understanding plants as living machines that are not only capable of articulating the connection between air and soil, but also allow to rebuild an ecosystem worn out by development, this project shows that landscape design can trigger processes at an ecosystemic level, avoiding the opposition between nature and technology.

n April 2019, the Ministry of Culture of Peru, the Municipality of Lima and the Centennial Group opened an international architecture and landscape call for the design of a 72-hectare Metropolitan Park on the perimeter of the Archaeological Sanctuary of Pachacamac, Lima. The initiative sought to protect the Sanctuary from future land occupations and provide the southern part of the city with a new metropolitan scale park on the occasion of the Bicentennial of the Peruvian Independence. The project "The Plinth and the Mantle" was the winner among more than 100 proposals.

Archeology and nostalgia are not synonyms... In Ychma and Inca mythology, Pacha Kamaq is the creator god of the earth. Its temple, located at the mouth of the Lurín River - south of Lima -, was one of the most important sanctuaries on the pre-Hispanic coast. Pilgrims came from all corners of the Tahuantinsuyo to worship the god who protected the inhabitants of the central Andes from the fury of nature and, above all, earthquakes. These rituals lasted over a thousand years, in a privileged sacred landscape, 


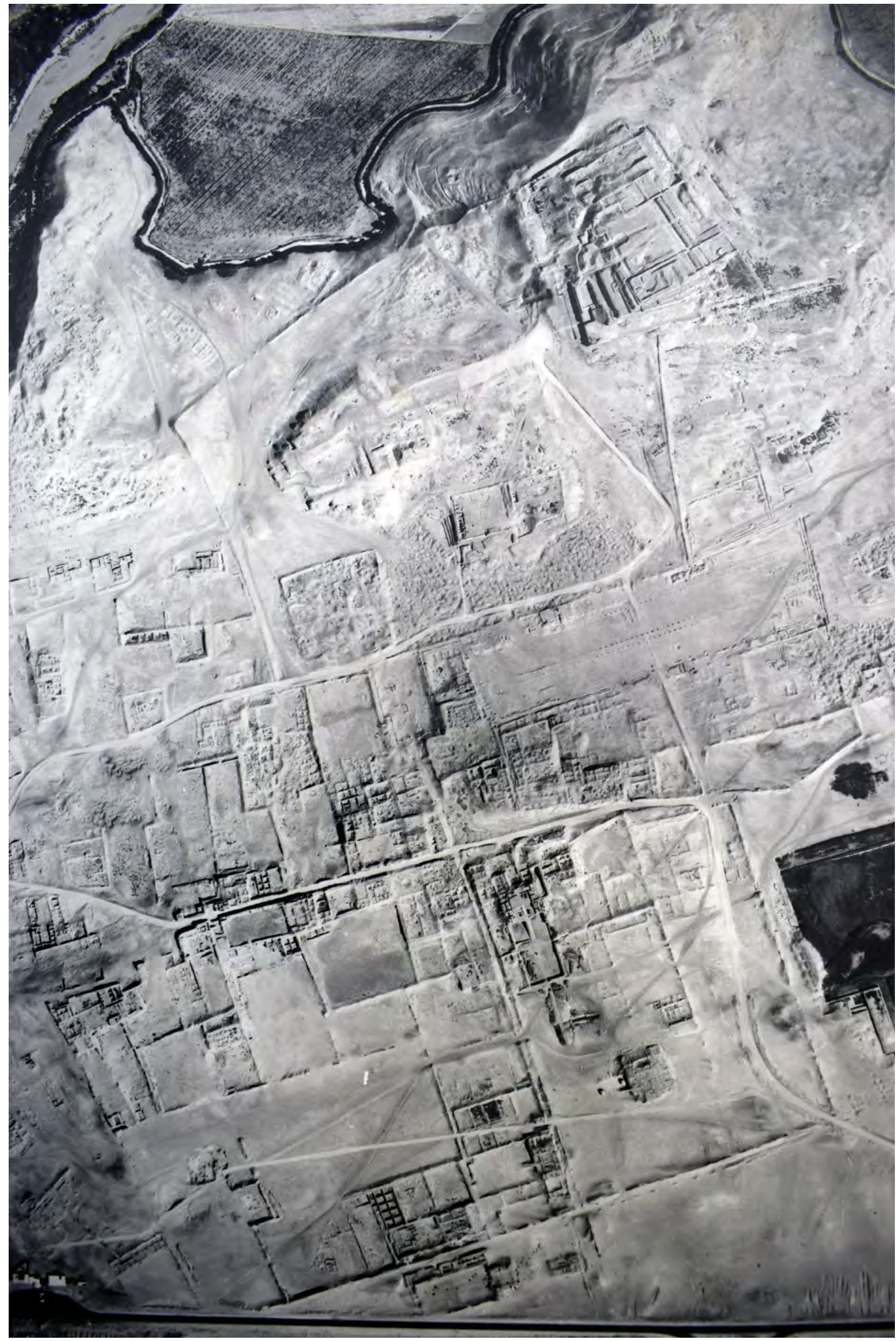

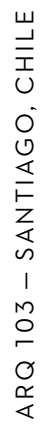




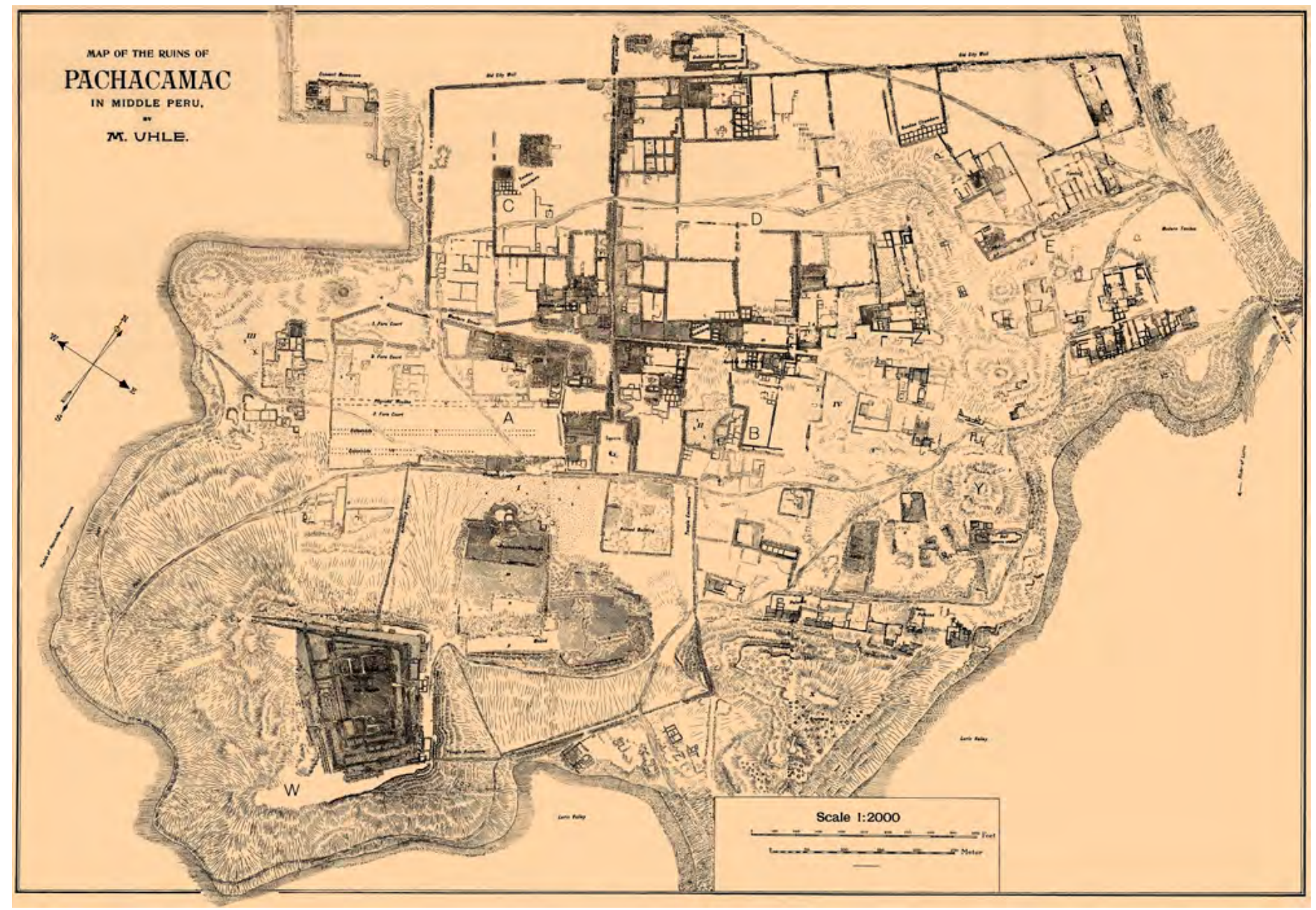

Max Uhle. Mapa de las ruinas de Pachacamac en Perú central, 1903 / Max Uhle. Map of the Ruins of Pachacamac in Middle Peru, 1903

(c) Museo Pachacamac located on a promontory next to the sea, the islands, and the valley. ${ }^{1}$

We set out to operate at the Pachacamac site, leaving aside historicist nostalgia. On the one hand, the site is not, nor has it ever been, culturally static. Different Andean civilizations were superimposing and adding temples, streets, and walls, in a process of landscape transformation that began around the year 300 A.D. and continues to modify the site today, in the $21^{\text {st }}$ century. ${ }^{2}$

On the other hand, Pachacamac is the result of the technical advance of the cultures that operated there. The development of new construction and water management technologies allowed the populations of the central coast to modify this arid territory to make it habitable. Thus, innumerable vestiges of this cultural overlay still lie underground in a land that appears to be abandoned. ${ }^{3}$

The site is currently flanked by human settlements that continually threaten to expand into the sanctuary, putting its archaeological conservation in a hard place. Faced with this, our response was to make a plinth strong enough to contain urban expansion, but flexible enough to adhere and reactivate existing public spaces in the perimeter. This is not only a 


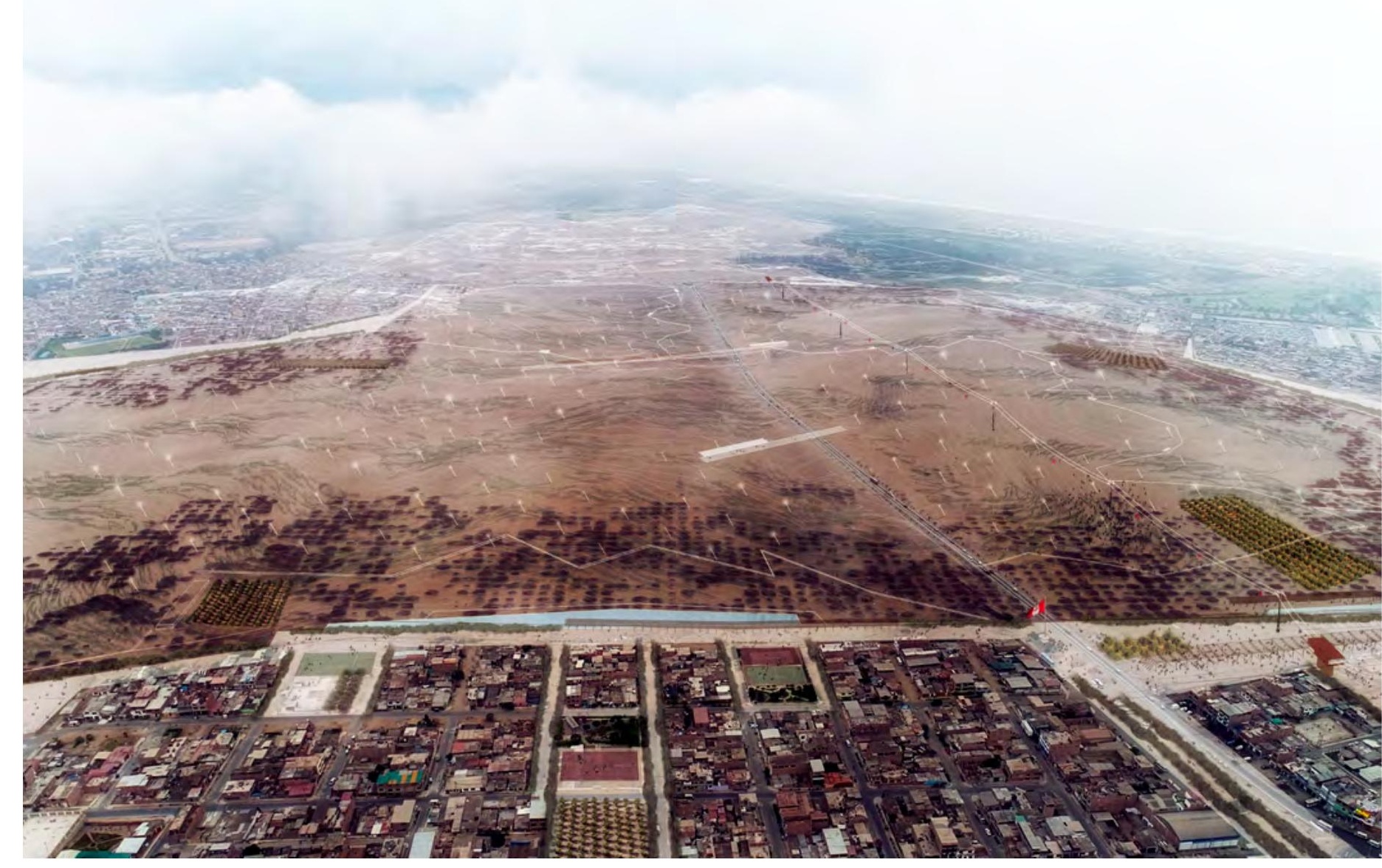

walkway and a horizontal limit for the park, it is also a landscape infrastructure that hides a series of small sewage treatment inside plants, which in turn clean and store the sewage of the neighborhood, turning it into irrigation water. As an artifact, the plinth transforms the problem of urban growth into the solution to irrigate the park.

\section{Ecology and progress are not antonyms...} The desert of the Peruvian central coast hosts a series of fragile ecosystems, endangered due to the exponential economic development that Peru experimented since the beginning of this century, indiscriminate logging and climate change. The lack of visibility and education about these natural systems of arid climate has contributed to the progressive deforestation of valleys, hills, and dunes, with the consequent loss of endemic species and the ecosystem services they provide. ${ }^{4}$ Our goal is to transform Pachacamac into an example of how to reverse this process.

The hills are one of the most sensitive and diverse ecosystems on the west coast of the South American desert, present intermittently over 3000 km - from Trujillo in the Peruvian Coastal Desert (8 degrees south latitude), to the Loa River in the

Pachacamac / Aerial view Pachacamac site (c) Alfaro, Lachhwani, Mckay 


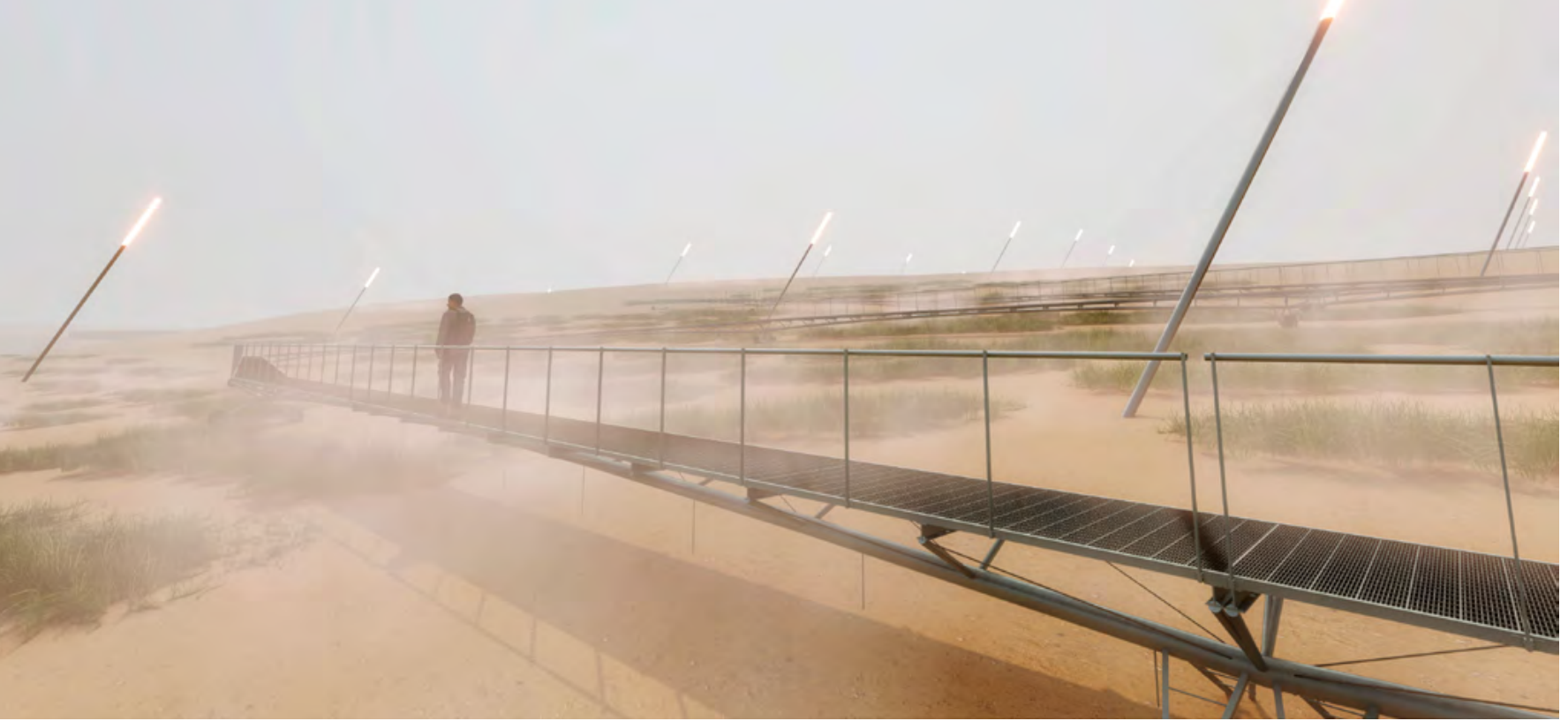

Tillandsial y pasarela de niebla / Tillandsial

and foggy walkway

(c) Alfaro, Lachhwani, Mckay

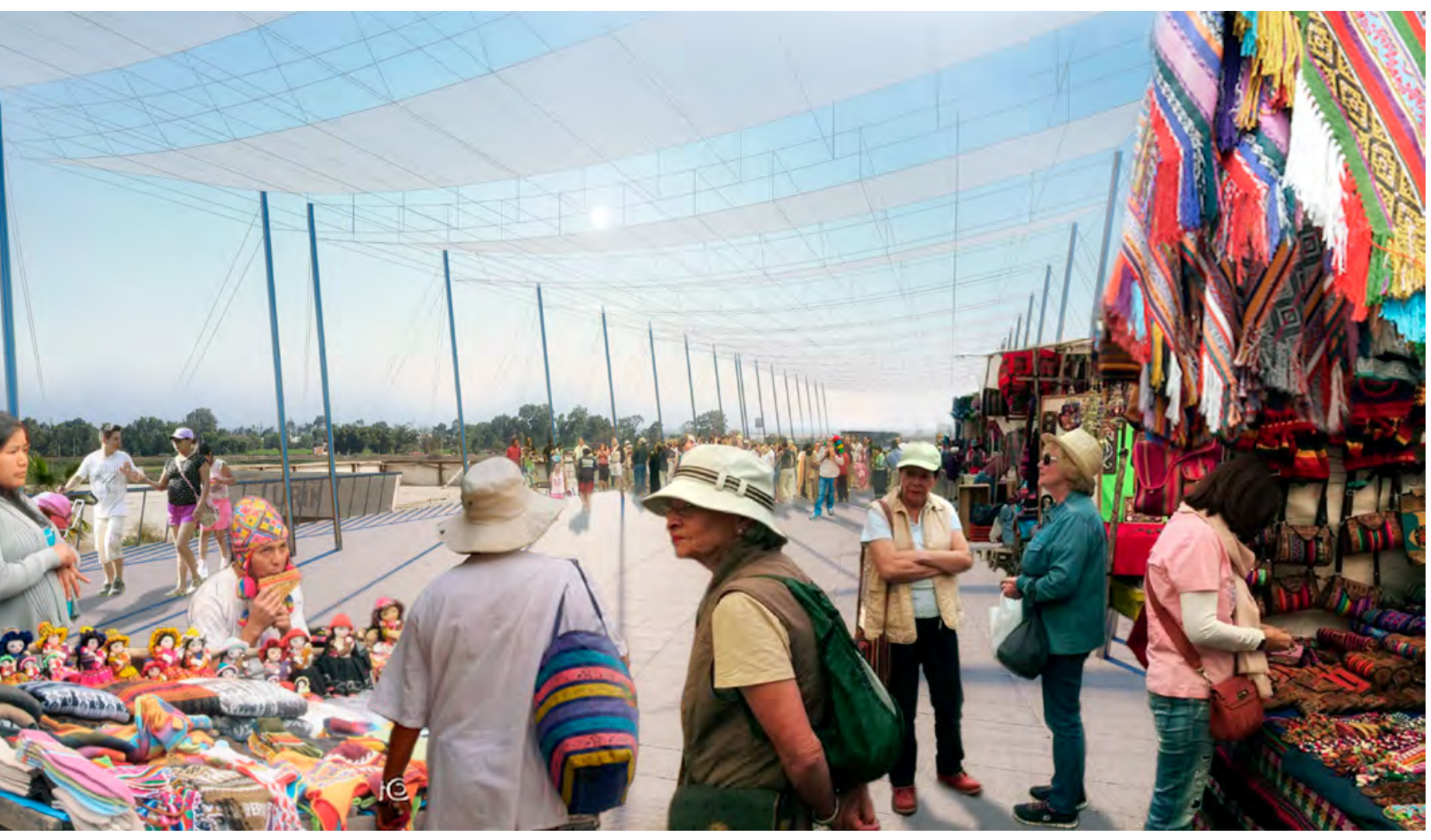

Mercado de artesanías /

Handicraft market

(c) Alfaro, Lachhwani, Mckay 


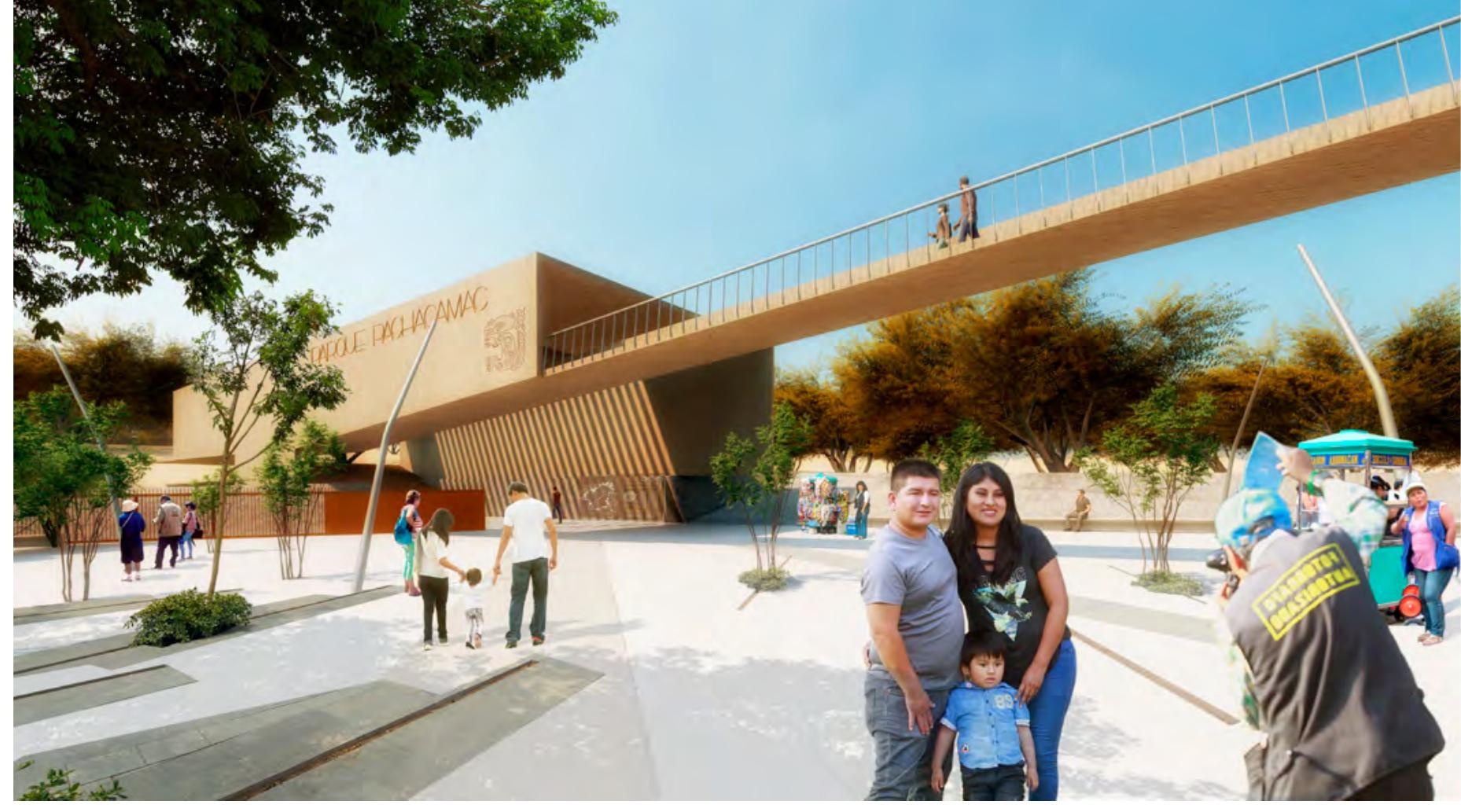

Acceso sur y puente de los museos / South access and museum bridge

(c) Alfaro, Lachhwani, Mckay

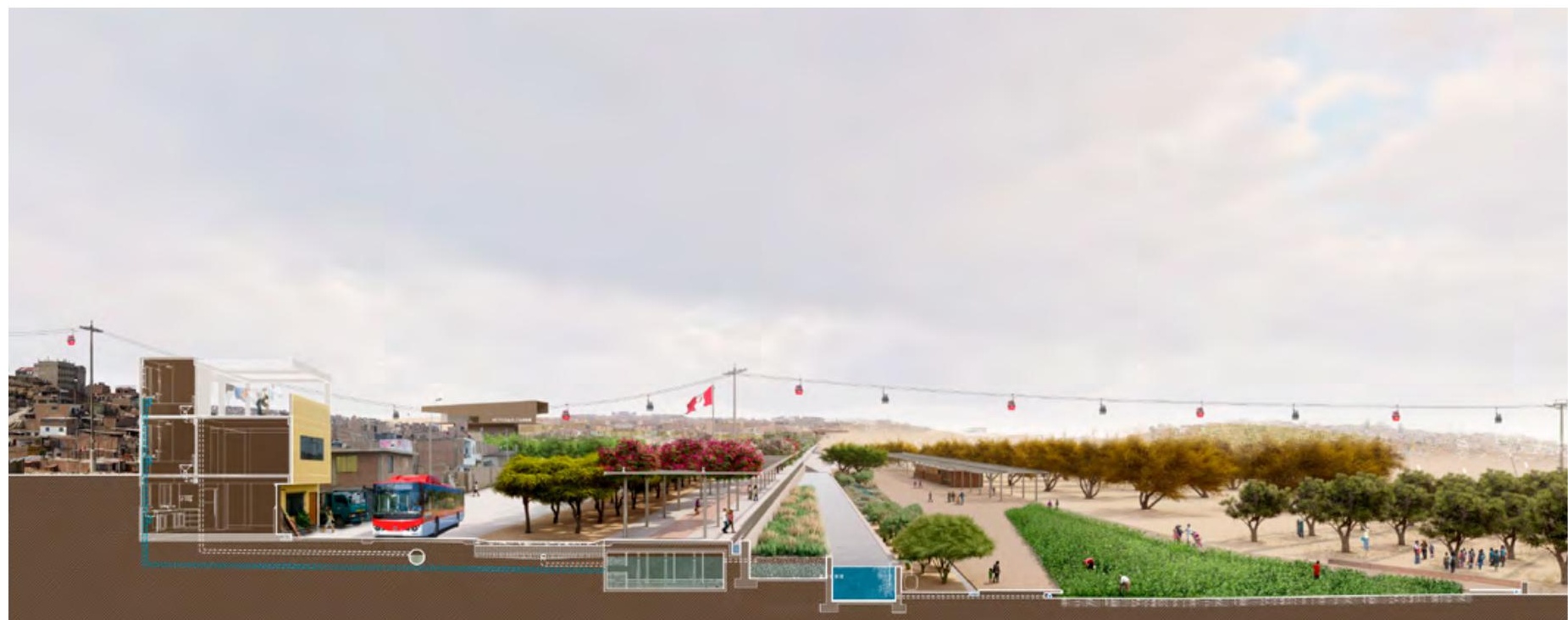


Plan Maestro / Masterplan

E. / S. 1: 7.500

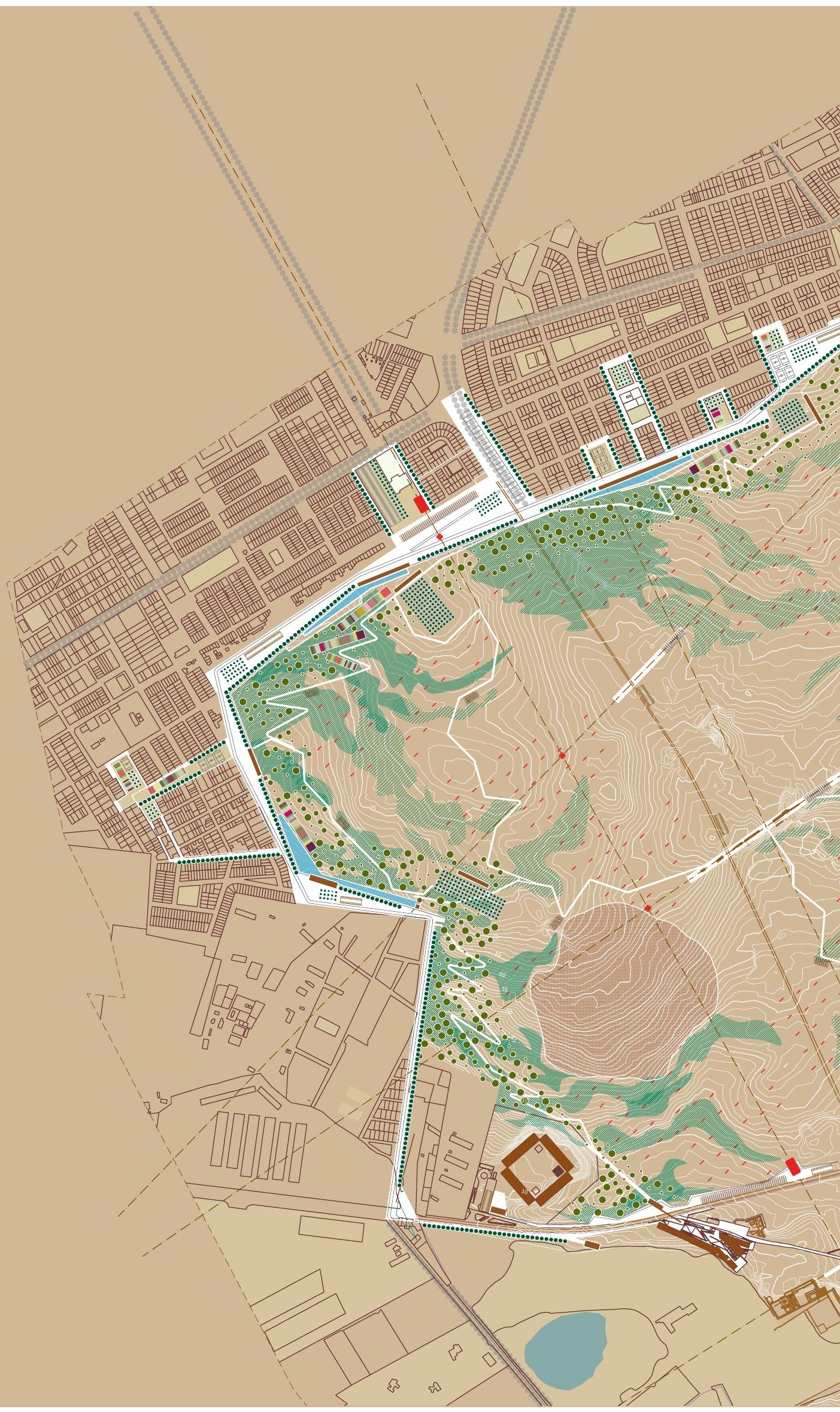




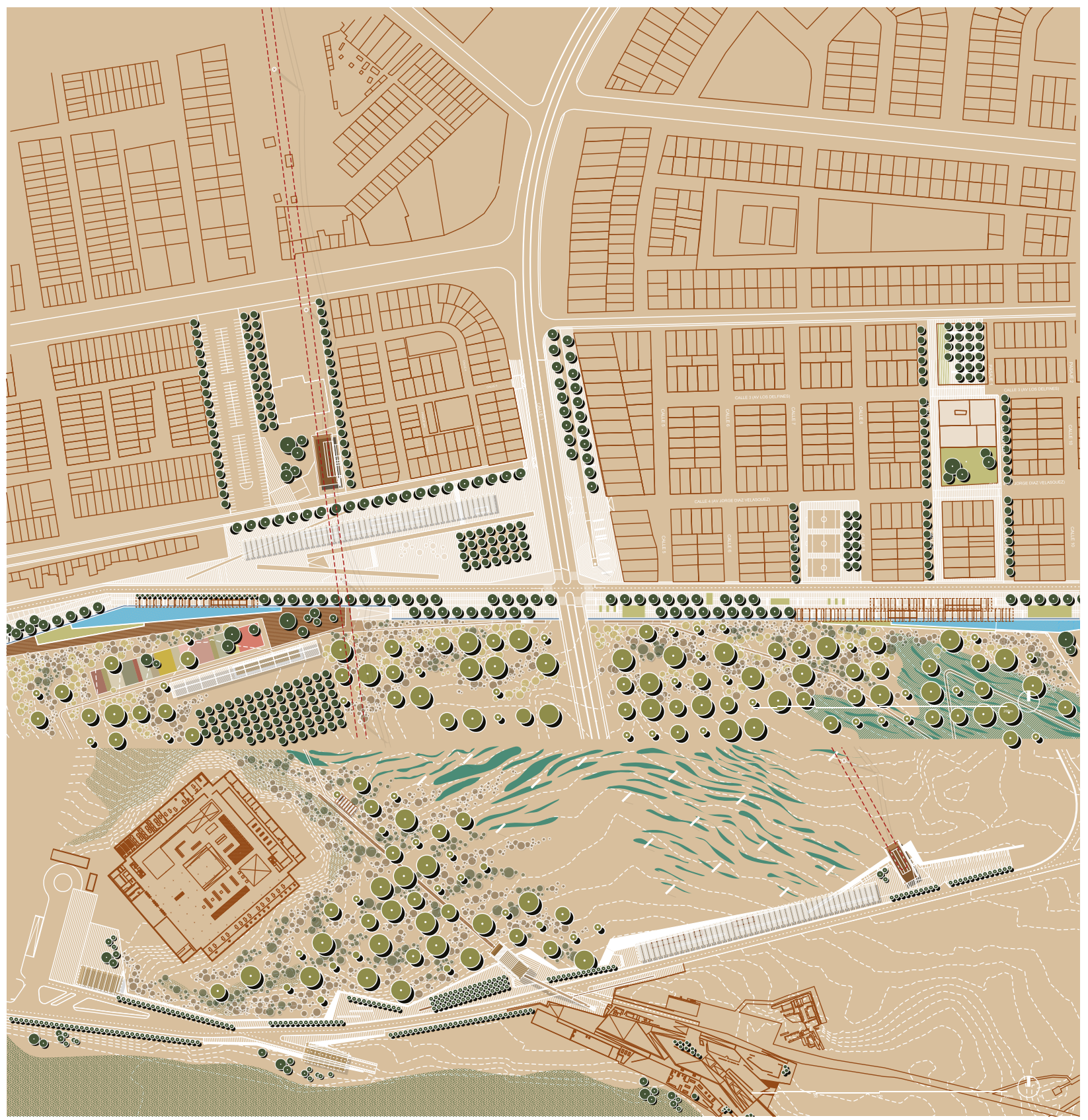


Atacama Desert (21 degrees south latitude) -. The fog, known as garúa in Peru and camanchaca in Chile, is its main source of water, watering the slopes of the coastal hills. The high humidity in the fog zone allows the development of vegetative formations called tillandsiales, where the sand extensions are covered by plants of the genus Tillandsia (Bromeliaceae). ${ }^{5}$

Several species of Tillandsia are 'epiphytic' and 'epiphyte,' that is, they feed on ambient humidity and have no roots. Their growth in parallel bands, facing the prevailing wind, makes them catch and accumulate sand, reducing the erosion of the slopes. ${ }^{6}$ For this reason, they are ideal for covering archeologically valuable soil.

Our strategy is to make ecology protect archeology. Taking as precedent the preexistence of tillandsias in the ruins, we propose the ecological restoration of the hills ecosystem on the site, which encourages the consolidation and creation of new dunes. The mantle is a Tillandsia blanket that completely covers the site, a living sand-accumulation machine to protect the soil and archaeological remains from wind erosion, which also provides ecosystem services to the surrounding neighborhoods. ${ }^{7}$ Together with the Tillandsia, a tamaruga $\left.\right|^{8}$ and a series of educational orchards cover the extensive dunes, using the water that is recycled in the plinth to irrigate the park through a new system of walkways and fog poles. ${ }^{9}$ These artifacts will be responsible for distributing and 'fogging' the water, generating a landscape of artificial fog several meters under the lower elevation of the clouds that permanently cover Lima.

In this case, the technological development and the progress will serve the creation of a new ecosystem and not its destruction. How natural or artificial this park is, does not seem to be the right question. Perhaps the question is how to artificially detonate a process of landscape change that at some point has a life of its own, beyond our control. Or, rather, at what time a park ceases to be a park and becomes nature, if such a thing is possible. In short, how to make our work disappear. Over time, the sand trapped by the mantle will cover every vestige of our actions, erasing ideas, making our technology obsolete. Then, our modest ruins will become part of the repertoire of objects that lie buried under tons of dunes.

... in Pachacamac, archeology and ecology will hold the same meaning. ARQ 


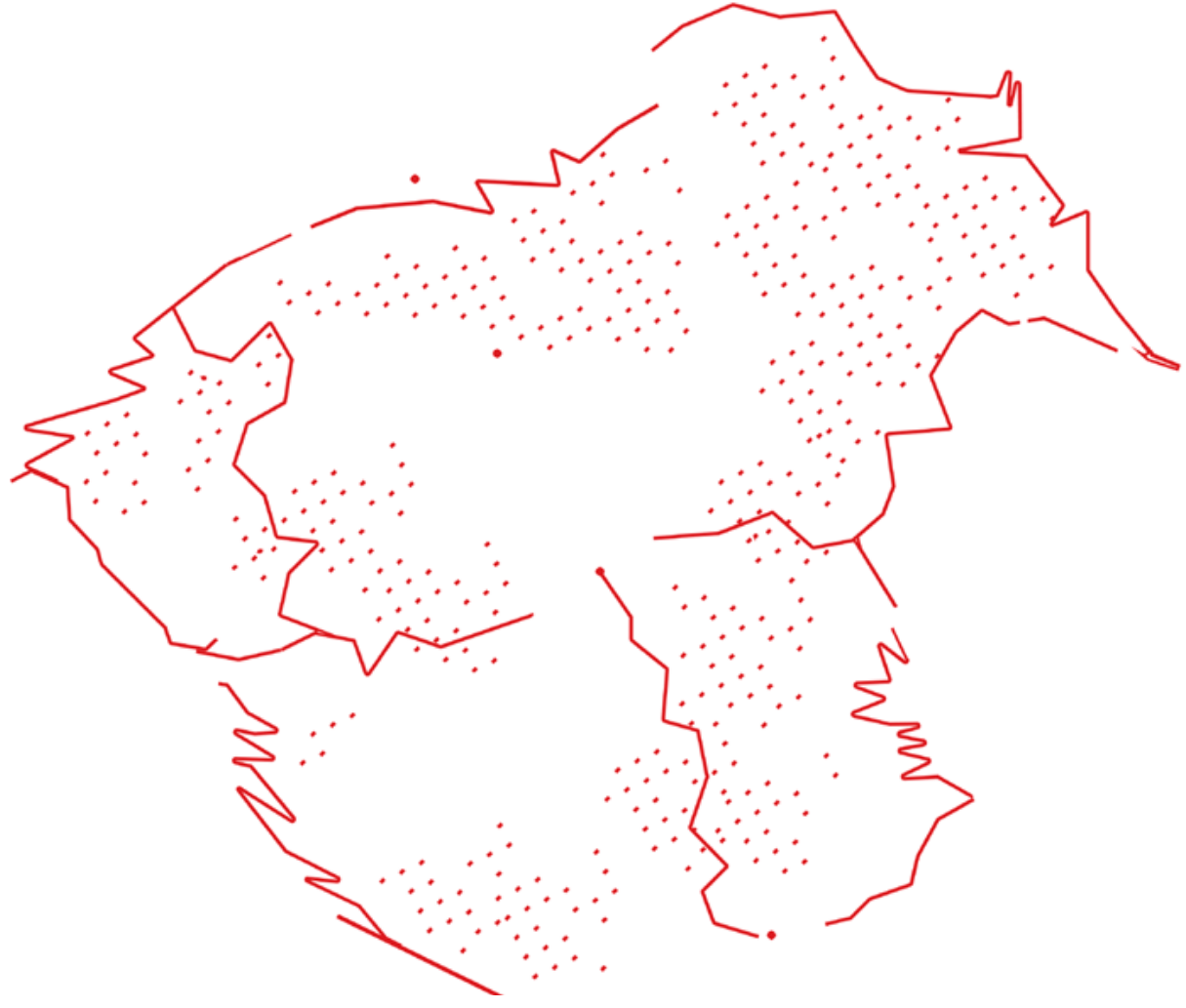

Planta tamarugales / 


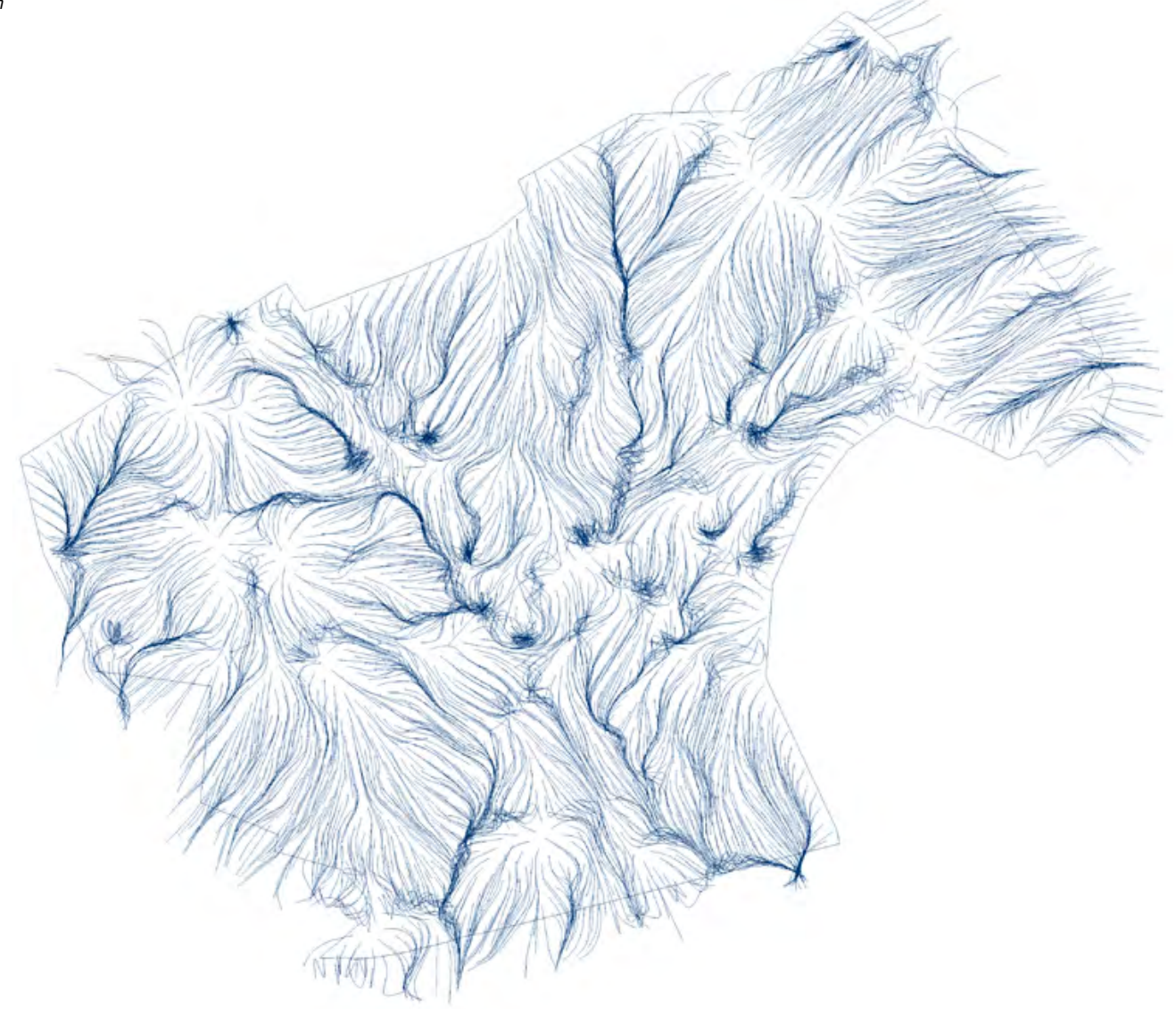




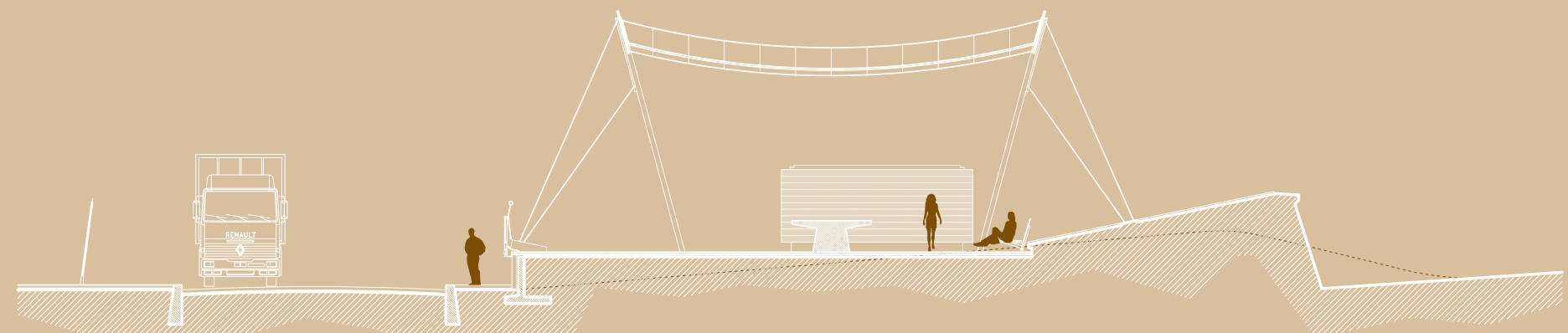

Corte BB zócalo urbano /

Urban plinth section $A A$

E. / S. 1: 250

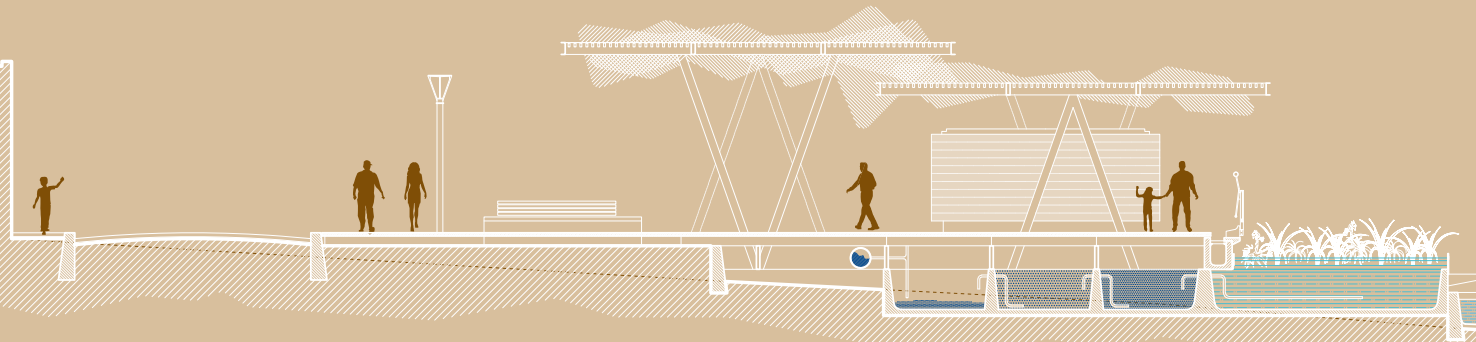

Corte AA zócalo urbano /

Urban plinth section $A A$

E. / S. 1: 250

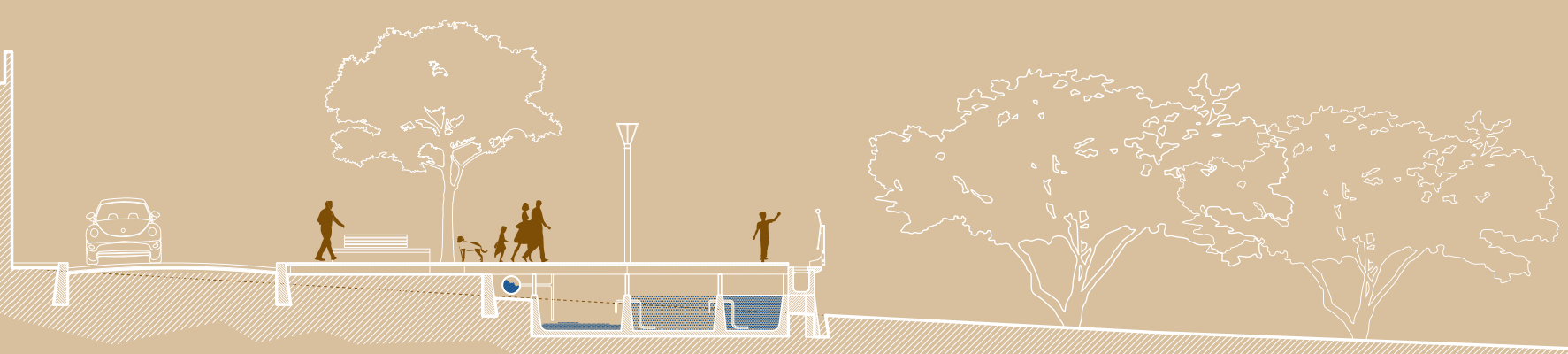




\section{Notas / Notes}

1 POZZI-ESCOt, D. Un Espacio Sagrado Milenario. Pachacamac: EI Oráculo en el horizonte marino del sol poniente. Lima: BCP, 2017. 2.

2 Ibid., 9.

3 CANZIANI, J. Construcción territorial y sacralización del paisaje. Pachacamac: El Oráculo en el horizonte marino del sol poniente. Lima: BCP, 2017. 50

4 Whaley, O. Plantas y Vegetación de Ica, Perú. Un recurso para su conservación y restauración. Icamanta Yurakuna Qurakuna. Lima: Darwin Initiative, 2010. 1.

5 PINTO, R. Geographical Distribution of Tillandsia lomas in the Atacama Desert, northern Chile (Center for Advanced Studies in Ecology and Biodiversity, and the Ecology Department at Puc Chile, 2016).

6 To provide habitat for endemic species, to alleviate the 'huaicos' impact (alluviums), to reduce ground temperature, among others.

7 HESP P. Nebkha flow dynamics and shadow dune formation. Geomorphology, 2017.

8 A 'tamarugo' (Prosopis tamarugo) or 'huarangos' (Prosopis pallida) plantation in a $20 \times 20 m$ grid.

9 The controversial 'fog poles,' contemplated in the contest, did not survive the client's criticisms.

\section{Pablo Alfaro}

<pablo@landmrx.com>
Pablo Alfaro. Architect, Pontificia Universidad Católica de Chile; Master in Landscape Architecture, California University Berkeley, USA.

\section{Kushal Lachhwani}

Kushal Lachhwani. Architect, School of Planning and Architecture New Delhi; Master in Landscape Architecture, California University Berkeley, USA.

\section{Tomás Mckay}

Tomás Mckay. Architect, Pontificia Universidad Católica de Chile; Master in Environmental Plannification, California University Berkeley, USA.

Arquitectos / Architects: Pablo Alfaro, Kushal Lachhwani, Tomás Mckay Ubicación / Location: Antigua Ruta Panamericana s/n, Lurín, Lima, Perú Mandante / Client: Ministerio de Cultura, Gobierno del Perú
Superficie construida / Built surface: 100 ha. Superficie total / Total surface: 250 ha.

Año de Proyecto / Project year: 2019 